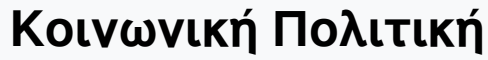

Tóp. 9 (2018)

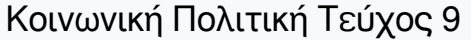

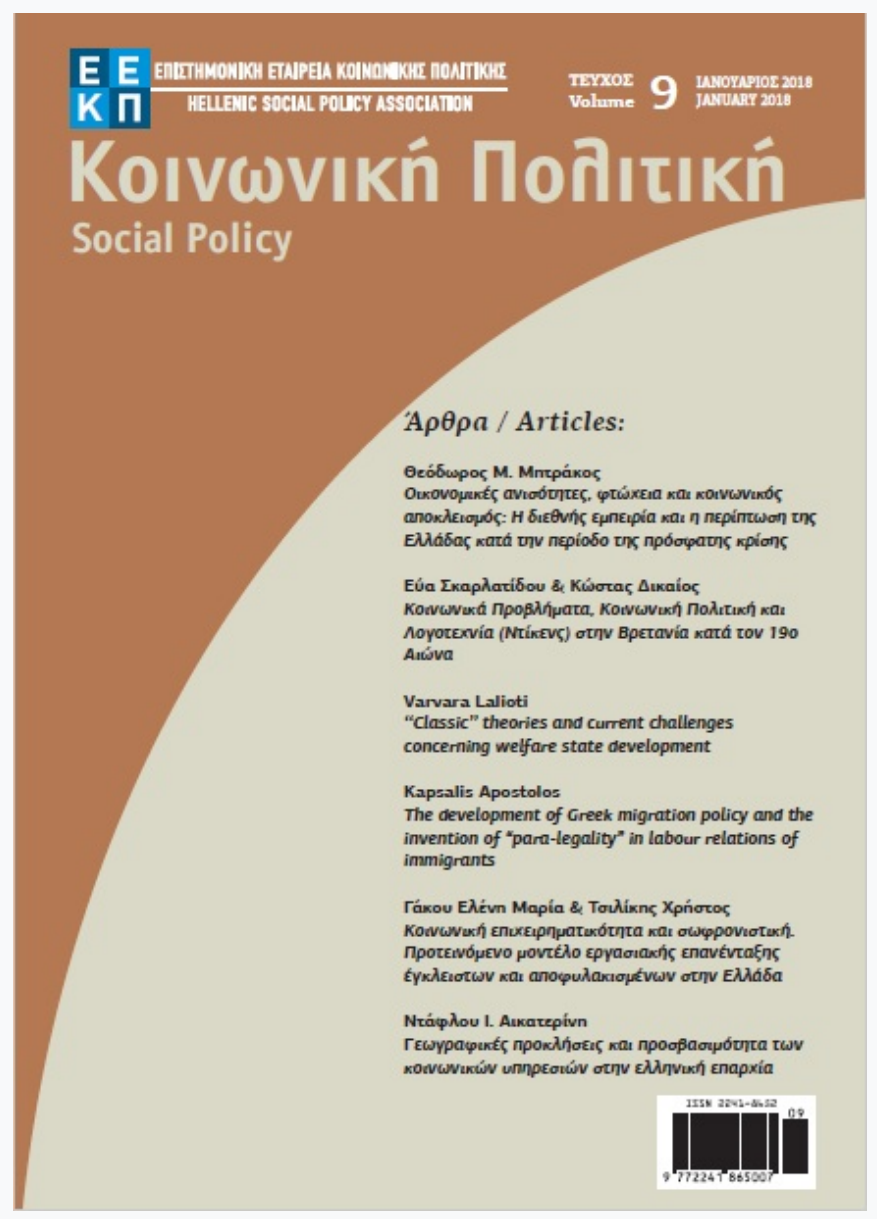

The development of Greek migration policy and the invention of "para-legality" in labour relations of immigrants

\section{Apostolos Kapsalis}

doi: $10.12681 /$ sp.15986

Copyright @ 2018, Apostolos Kapsalis

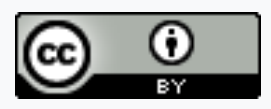

Ađ¿ıı xpńons Creative Commons Avapopá 4.0.

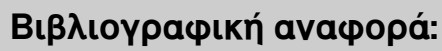

Kapsalis, A. (2018). The development of Greek migration policy and the invention of "para-legality" in labour relations of

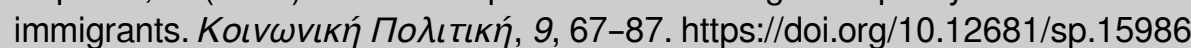




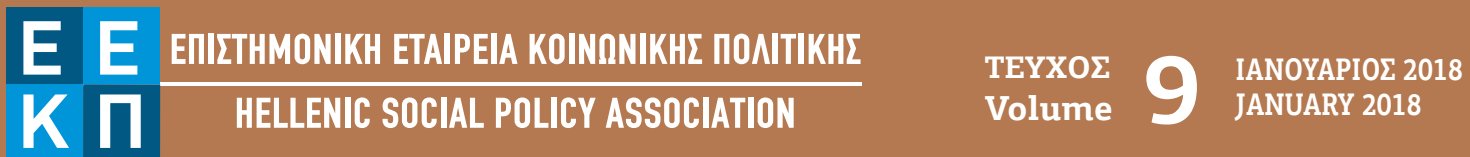

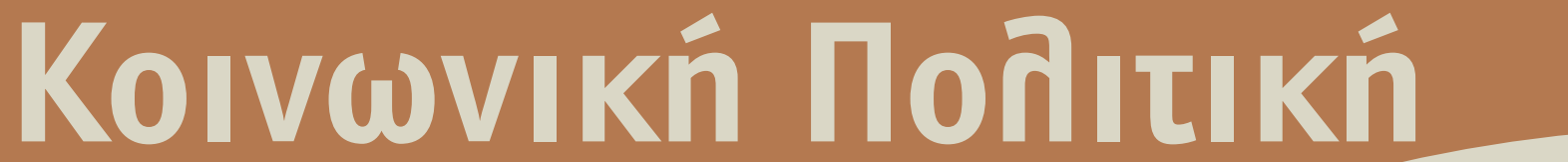

Social Policy

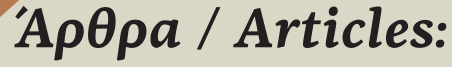

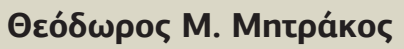

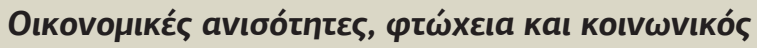

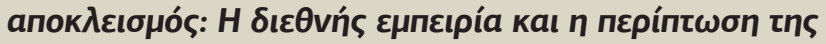

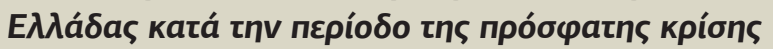

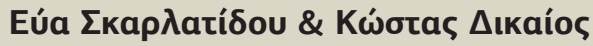

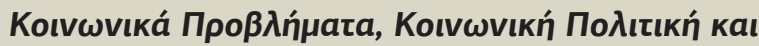

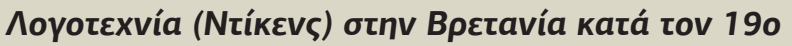
Aıćva

Varvara Lalioti

"Classic" theories and current challenges concerning welfare state development

Kapsalis Apostolos

The development of Greek migration policy and the invention of "para-legality" in labour relations of immigrants

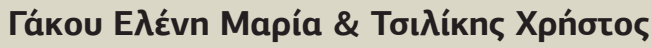

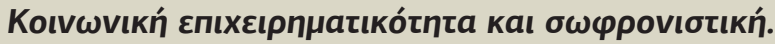

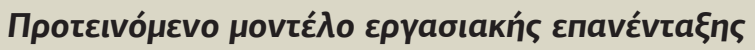

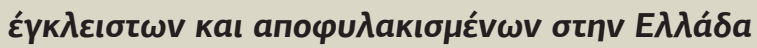

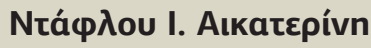

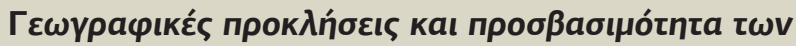

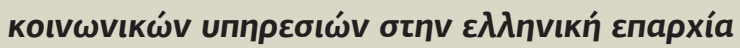

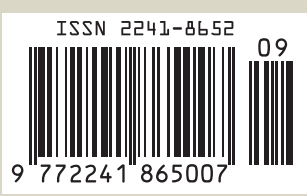




\title{
The development of Greek migration policy and the invention of "para-legality" in labour relations of immigrants
}

\author{
Kapsalis Apostolos \\ Faculty of Social Policy, Panteion University
}

\section{Abstract}

The management of the upsurge in migratory flows since 2015 and in particular the irregular entry and residence of thousands of newcomers in Greece pose significant challenges for national migration policy. The long course of legislative interventions to regulate irregular immigration into the country has recently introduced a new station, the concept of paralegality. This is the legislative recognition of a new category of immigrants in the midst of the standardization of the theory so far, based on a special version of the legality of residence. The formalities of the new arrangements, on the one hand, are part of the revival of a traditional work-based approach to immigration policy and, on the other hand, they reaffirm the state choice of discrimination in the labour market to the detriment of migrant workers based on an axis of subjective characteristics.

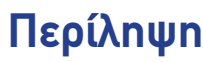

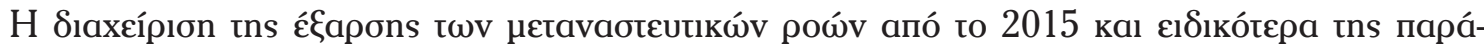

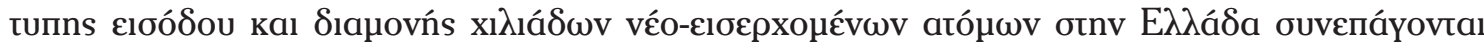

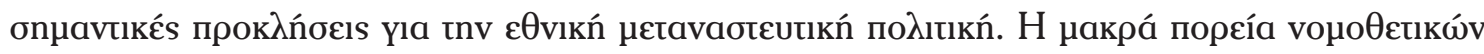

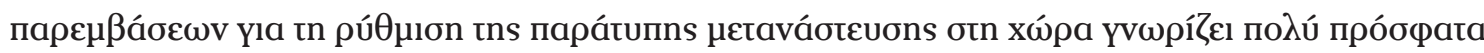

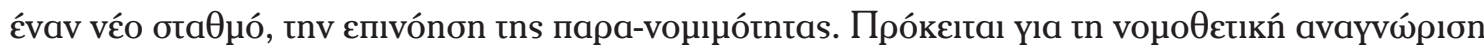

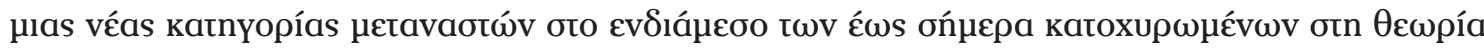
типопои́б

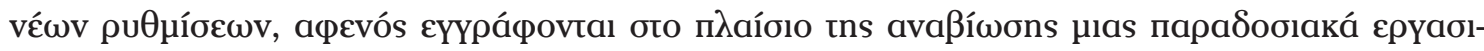

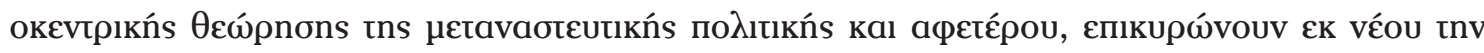

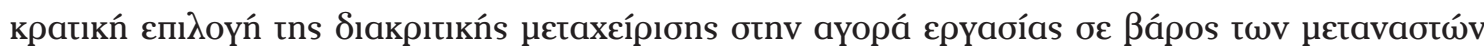

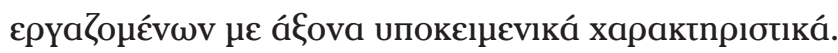




\section{Introduction}

Immigration flows in Greece in the period 2015-2017, particularly in the context of the economic recession and the crisis, bring to the forefront of the social agenda the issue of an appropriate "management" policy or the legal treatment of newcomers. Although the financial arguments are not absent, the distinction between refugees and economic migrants is proving difficult given that the populations in transit from Asia or Africa to Europe are mixed and the legal identification of the real cause of their mobility is precarious (Banulescu-Bogdan and Fratzke, 2015). While these mixed human flows (ESC, 2016) concern in reality a humanitarian migration crisis, the governments of many host countries and international organisations often attempt to identify this phenomenon with traditional or classic refugee flows and, in many cases, the former is deployed to consolidate a climate of generalised insecurity, in an environment of increasing xenophobia and islamophobia.

Over the years, in the field of international relations, all modern host states, in support of a public image of unimpeded exercise of their national sovereignty (Rosenblum, 2014), are engaged in a persistent effort to control or manage migratory flows. These controls towards aspiring immigrants take place on two levels, one external and one internal (Hollifield et al, 2014).

The first level of control concerns the external borders and includes all the police, administrative and technological means of monitoring, detecting and preventing the entry into the territory of all those who have not obtained the required accreditation. The second level concerns the internal borders and, particularly, the search, detection and removal of "irregularly" arriving and staying immigrants. In particular, many states, such as the Greek and the Italian (Triandafyllidou and Ambrosini, 2011), are not only confined to the raising and shielding of these external and internal enclosures (metaphorically and literally), but also create certain protective gates at both these levels. These gates consist of regulations and mechanisms both for preventing irregular and undesirable immigration, and impeding access by unwanted foreign nationals to the national labour market and, consequently, to the health, education and social protection systems of the host country.

Over the time, Greece has had a considerably low degree of effectiveness in controlling its borders in terms of enclosure and deterrence. Inevitably, the Greek state has been systematically turning to the second possibility left in order to convince the public opinion that it is in control of the situation: the creation of gates for the protection and filtering of incoming migrants, especially concerning the labour market. Meeting this need involves two sets of interventions.

The first one is implemented in advance and concerns the organisation of legal migration. The two versions of legal migration, invitation/ metaklisis procedure and seasonal work, as applied from 1991 to date, concern almost exclusively the agriculture industry, are under review for their effectiveness, are dominated by inherent distortions and are subject to serious objections in relation to serving the purpose of covering actual and confimed needs in the Greek labour market (Kapsalis, 2018). The predominant element of the Greek version of legal migration for employment purposes is the element of selectivity, which, nevertheless, provides 
ground for political exploitation of the issue and inflates the scope of undeclared work.

This selectivity is not based on qualifications, specialization, skills or actual demand for a foreign workforce, but on criteria whose definition may in many cases be arbitrary or the product of expediency and could risk violating the principle of fair treatment and intensifying social exclusion (Papatheodorou, 2015). In addition to the arrangements for invitation/ metaklisis system and seasonal work, Greece has not provided for the design of legal entry and employment programs focusing on temporary and mainly circular migration (Gemi et al., 2010).

The second set of interventions by the Greek state focuses on the post hoc preservation of the entry gates into the labour market against immigrants without residence permit who have already crossed the external and internal borders, either in an official or irregular way. This article attempts to analyze a recent legal invention regarding the legality of residence and employment of aliens in Greece, which may be called para-legality. The assessment of the new regulation is realised on the one hand, through the evaluation of irregular migration policies that have been pursued for almost the last thirty years (Chapter 2), and on the other, by focusing on specific theoretical tools concerning the legal construction of illegality in the fields of migration policy and industrial relations (Chapter 3).

\section{2. "Legalisation" (?) of immigration}

The failure to control migratory flows has led Greek migration policy to an almost exclusive orientation towards those already established in Greece (ESC, 2004). The state has to deal with two major categories of people in its attempt to safeguard the labour market from the unauthorised or irregular employment of immigrants. The first category includes immigrants who have a residence permit or even an entry visa, but not the right to work or, in any case, the ability to work where and as they wish. The second and most extensive category includes migrants who have no longer or never had a residence permit and therefore are not allowed to work in the country.

The states have three post factum options concerning the phenomenon of irregular immigration: a) the expulsion and deportation of immigrants; b) the tolerance of their presence; and c) the normalization or regularisation of their residence status (King and DeBono, 2013; Baldwin-Edwards, 2004). In the Greek case, emphasis is periodically placed on each of these three versions of a state response, yet considering the official legislative interventions over time, it can be concluded that all these three categories of actions can be deployed simultaneously and selectively.

During the first decade of modern mass immigration towards Greece and until the late 1990 s, the intensity of deportations combined with tolerance in the permanent presence as well as the undeclared employment of hundreds of thousands of immigrants is being chosen. In the period between 1991 and 1997, 1.5 million deportations are estimated, the vast majority of which are Albanian citizens (Konsta and Lazaridis, 2010). Since the early 2000s, state priorities have changed. 
Initially, the practice of arrests and deportations never subsides. According to data provided by the Ministry of the Interior, in the period 2006-2015, 175,000 foreign nationals, most of them of Albanian citizenship (Kotzamanis and Karkouli, 2016), are deported. In addition, the provision for the recording and selective normalisation of immigrants' residence status is implemented as an emergency solution (Rodier, 2001), accompanied by extensive tolerance, both for the permanent preservation of a large proportion of immigrants in an unofficial status and for the continuous feedback of this tank with newcomers or already established immigrants.

In the absence of specialised and well-developed programs of organised immigration or social integration, education, housing and employment of immigrants, the majority of legislative interventions in Greece is indetified with or focused on the central "legalisation" initiatives in $1998-2001^{1}$ and $2005-2007^{2}$ (Kapsalis, 2018). Although the main regulations in the field of alien status law are not limited to the issue of undocumented migrants, the large number of persons concerned and the social importance of the provisions for recording and regulating their residence, result in the relevant literature being focused on procedures of assigning and renewal of residence permits in the context of regulating unofficial immigration. From a point of view (ICMPD, 2009a), in fact, Greek migration policy is, predominantly, a normalisation policy, that is, a policy of post-hoc "legalisation" of irregular immigration.

Regarding the term legalisation and synonymous terms regularisation or normalisation and amnesty (Maas, 2010), it should be clarified that, especially in English language, a conceptual clarification is often attempted, as each of these terms bears a different ideological sign or refers to a distinct type of legislative intervention (Chauvin and Garcés-Mascarenas, 2012; Brick, 2011; Papadopoulou, 2005). The same applies to the definition of migrants as unofficial, irregular, illegal, sans papiers, undocumented, unauthorised, clandestine, in the scientific and everyday language (Bansak, 2016; King and DeBono, 2013).

Organisations, which are involved in the field of migration and refer to human and civil rights, question the terms illegal immigration and illegal immigrants, due to the fact that these terms directly refer to delinquency and criminal offenses (Flynn and Duvell, 2007). In Greece, the term of the campaign or initiative of legalisation or normalisation of the residence status seems to have prevailed, although it is preferable for the subjects of transnational movements that the offensive designation illegal be avoided and the terms unofficial or irregular be preferred instead.

According to the definition proposed in the context of the European program REGINE, the "legalisation" program is "a special normalisation process, which, initially, does not form part of the legal immigration framework, secondly, lasts for a limited period of time, and thirdly, aims at special categories of non-natives under unofficial status"(ICMPD, 2009). This definition falls entirely within the Greek case, while these three characteristics of the "legalisation" programs are largely common at European level, particularly with regard to all southern countries.

The case of Greece is not classified in the category of countries that use the "legalisation" campaign as a goal, in the context of a strategy inspired by humanism or respect for funda- 
mental rights. On the contrary, it belongs to the group of host countries, where the programs of mass normalisation of immigrants' residence status are governed by a regulatory and labour market oriented logic. In the relevant literature, such countries at a European level are mainly Italy, Spain and Greece, where 75\% of the total "legalisations" of this type have been implemented (Lazaridis, 2015) and in which 84\% of all "legalisation" requests have occurred in the period 1997-2007 (Bansak, 2016).

According to the prevailing opinion, in these countries, "normalisation" programs constitute a means in the effort to achieve wider employment and social security aspirations, as particularly happened in Spain in 2005 (Schweitzer, 2014; Mc Govern, 2014). Nevertheless, in the Greek case, only at a declarative level, and only recently in the case of the Immigration Code (Law 4251/2014), the state's intervention is attempted to be justified as part of a more comprehensive plan to combat undeclared work and strengthen social rights or, more widely, social inclusion of undocumented immigrants.

From the total relevant literature, a specific typology of this South European model emerges (Baldwin-Edwards, 2004), although the Greek version diversifies in some of its aspects. Besides, all south-European countries are characterised by a large scale of informal economy, extensive rural and other labour-intensive sectors, as well as significant demographic problems accompanied by a deficient welfare state. The convergence points of the Greek policies for the normalisation of the residence status of irregular migrants regarding the main features of this South European model are the following seven:

a) Work-based logic. This particular approach, consistently dominant until 2014 in the case of Greece (Kapsalis, 2012, 2007) or Spain, especially after 2005 (McGovern, 2014), characterises, in general, the "legalisation" programs in all southern European countries, which replace the absence of a comprehensive national policy on economic migration (ICMPD, 2009). This logic concerns the normalisation of the residence status for more than 3.8 million irregular immigrants, who have benefited from one or more of the 23 programs in Greece, Italy, Spain and Portugal until 2008 (Kraler, 2009).

In the context of the "legalisation" programs, the dependence of obtaining a residence permit on criteria that are connected, even indirectly, to employment, is common even in the case of northern countries that traditionally deploy humanitarian criteria to regulate unofficial immigration (Chauvin et al., 2013; Finotelli and Arrango, 2011). The concept of earned normalisation refers to a tendency of European case law to include the factor of work in the criteria of successful admission to the host country, and thus the conditions of the subsequent "reward" of the successful candidate, who in this way permeates the scope of regulations that usually apply to humanitarian programs.

b) Program eligibility criteria. As a result of the aforementioned element, the "legalisation" programs set specific conditions for participation with regard to the time of entry into the country, the conclusion of an employment contract, the contribution to the Social Security System and the acquisition of a certain minimum income, the proof of family ties with legally resident persons and the need for humanitarian protection. Usually, however, a combination of most of these criteria is observed (Brick, 2011; Maas, 2010; Papadopoulou, 2005; Rodier, 2001; Nascimbene, 2000). 
c) Difficulties in participating in procedures. Bureaucracy, high costs and difficulty in gathering the required documentation are recorded as deterrents in all southern European countries. In Italy, (Reyneri, 2001) it is estimated that in 15\% of cases, applications for participation in "legalisation" programs were based on fake labour relations. Nevertheless, specific reforms for the benefit of immigrants, especially as regards the conditions for proving the labour relation, resulted in the rate of acceptance of applications for residence permits to increase in that country from 40\% in 1986 to $91 \%$ in 2003 (Papadopoulou, 2005), although often the participation in the program is considerably less than expected, especially when it comes to domestic workers (Mc Govern, 2014). A great many immigrants in Spain, Greece and Italy do not manage to submit a participation application in these programs in the absence of any evidence or proof that usually involves the labour market. In any case, from the point of view of the bureaucracy of the irregular immigration control procedures, Greece is considered the most problematic case (King and DeBono, 2013).

d) Post hoc interventions in faits accomplis. Without particular emphasis on preventing irregular migration by focusing on organised movement programs, the countries of Southern Europe follow the practice of addressing the fait accompli (Papadopoulou, 2005) of long-term residence without residence permits of a large number of immigrants, when the situation "cannot go any further". It is a conscious choice for an a posteriori attempt to regulate immigration, since over the decades state reactions have been recorded almost exclusively post factum to an already established social and economic phenomenon (King and DeBono, 2013).

e) Temporary solutions. Short-term residence permits and return to unofficial status, also known as "de-legalisation" or "de-regularisation", are two fundamental common features of these programs. 50\% of immigrants who successfully participate in the 1991 program in Spain return to unofficial residence status three years later (Papadopoulou, 2005). Immigrants in Greece have been faced with the same problem consistently. In the first phase of the "legalisation" program in 2005, more than one-third of the applications are submitted by immigrants, who were previously legal, but had slipped into illegality (Cavounidis, 2012). The phenomenon of issuing expired residence permits or on the verge of expiration is not exclusively a Greek phenomenon, but is a major concern for Italy and Spain as well (Finotelli and Arrango, 2011; Balch, 2010).

f) Exceptional procedure. Campaigns for regulating irregular immigration are dominated by the official warning or declaration that it is an exceptional or "one-off" and rather an ex gratia procedure, which is not to be repeated in the future (Finotelli and Arango, 2011 Brick, 2011; Maas, 2010). The repetition of normalisation programs signals the reluctance to grant permanent or long-term residence permits, and simultaneously the inability to control irregular immigration (Papadopoulou, 2005).

At this point, a distinction is made between two different methods, the "legalisation program" and the "legalisation mechanism" (McGovern, 2014; Schweitzer, 2014; Brick, 2011; ICMPD, 2009). The first method involves an exceptional procedure, lasts for a certain period of time, sometimes focuses on specific categories of migrants and is not part of the policy context for legal immigration. The second method, on the contrary, refers to procedures through which a state can grant access to a legal residence status on a permanent basis and to the context of wider policies for legal immigration. 
g) Criticism for attraction and approval of irregular immigration. The northern EU countries, as well as international organisations such as the OECD and the European Commission, criticize the policy of repeated "legalisations" (McGovern, 2014; Schweitzer, 2014; Finotelli and Arango, 2011; Brick, 2011; Balch, 2010; Doomernik and Jandl, 2008, OECD, 2000) for four main reasons: a) because they constitute a clear confession of the failure to guard the external and internal borders, b) because they end up "rewarding" delinquency, c) the fear of free establishment on European territory and access to all other national labour markets of the "legalised" migrants in other (southern) countries, and d) because the repetition of the normalisation programs eventually operates as a pull mechanism of new irregular immigrants due to their arguable expectation for "legalisation" in the future.

Therefore, even if in the context of legal texts concerning aliens, provisions are included by which the normalisation of the status of retaining or acquiring residence permits is facilitated, their characterisation as "legalising" irregular immigration procedures is carefully avoided. This tactic has been recently adopted in the case of Greece, both in 2014 (L. 4251/2014) and 2015 (Law 4332/2015), and meets to a greater extent the needs of the political management of the irregular immigration issue within the country, than the legal commitments within the European Union.

The Greek "legalisation" programs differ, however, from the equivalent in other southern European countries in specific fields.

First and foremost, in Greece, as in Portugal, the permanent absence of an official mechanism for the evaluation of "legalisation" policies is observed, in opposition to Italy and especially Spain, which have developed methods and tools to monitor the effectiveness of the programs for regulating the residence status of unofficial immigrants in the fields of labour market and social policy (Bansak, 2016; ICMPD, 2009).

Secondly, the successive procedure for the issuing of two permits, work and residence, for as long as the relevant provisions were in force, is a Greek originality, particularly since the work permit was a prerequisite for residence permit for work purposes. The same applies to the reintroduction of a special version of work permit without a right of access to a residence permit, which was introduced in 2016 for specific professional categories of aliens (see 3.2 below).

Thirdly, a considerably low degree of participation and successful completion of the "legalisation" procedure is recorded continuously from 1997 to 2014, at least as in terms of reducing the extent of illegal immigration in Greece in comparison to other countries (ICMPD, 2009).

Fourthly, as already mentioned, in certain cases and in countries such as Spain and Italy (2002), the person applying for the residence permit program may be the employer and not the undocumented migrant (Brick, 2011). On the contrary, in the Greek case, the person responsible is always the immigrant, regardless of whether the role of the employer in concluding a written employment contract or in attaching the social security stamps/ ensima remains for many years determinant for the "legalisation" of the residence status.

Fifthly, the extensive national diversity, as far as the countries of origin of migrants are concerned, is a typical characteristic in all southern European countries except Greece (King and DeBono, 2013). In the Greek case, the organisation of programs for the regularisation of informal immigration still brings more favorable conditions (Kapsalis 2018, 2007), due to the 
significant population particularities, especially the high ethnic and geographical homogeneity of immigrants in their countries of origin.

Sixthly, in Greece the criteria for participation in all "legalisation" programs focus almost exclusively on the proven presence of the migrant on the territory up to a certain point in time and on the element of the employment relationship, and only subsidiarily or complementarily to family, humanitarian or health factors. Consequently, there is no focus on other criteria, such as nationality, level of integration, occupational activity or sectoral priorities (Schweitzer, 2014).

In Spain in 1994, the emphasis was placed on family ties, in Portugal in 1995 on immigrants coming from former colonies or, in Italy in 1996, on those coming from Albania, Morocco and Tunisia, although the human rights movement considers this kind of preferences as unfair discrimination (Papadopoulou, 2005). In Italy, the 2009 program focuses on employees working in the residence of the employer and on those in the field of welfare and social protection (Mc Govern, 2014), in which approximately 30,000 applications are submitted by employers concerned (Koehler et al., 2011).

\section{The construction of illegality: from the object to the subject}

A key question about understanding Greek immigration policy (as well) remains, however, unanswered: what does exactly the host state legalise? What is the aim of the "legalisation" of immigration and what is the role of the work of migrant workers in this process?

First and foremost, it should be clarified that, in practice, the system of authorising irregular migrants in Greece cannot be considered as an entry gate into the labour market, since such a gate has already been violated. It can also not be considered as a way of access to the official or legal labour market, since the residence permit neither does automatically ensure nor guarantee in the medium term the employment of "regularised" immigrants in terms of full legal compliance.

The Greek migration policy, which, as mentioned, is almost identical to the post-hoc workbased "legalisation" programs, translates into a conditional provision of short-term residence permits, thereby creating an entry gate to legality, which opens and closes as it pleases in the light of the economic needs or priorities of the politician in charge. The absolute understanding of the concepts of legality, legalisation and migrant worker is a prerequisite for the interpretation and evaluation of the Greek migration policy.

\subsection{Legality and semi-legality}

First of all, it should be clarified that irregular immigration is a side-effect: it is inevitably linked to the definition, as well as to the flexible interpretation of regularised and legal immigration. Without legal immigration, there would be no concept of irregular immigration (King and DeBono, 2013). In fact, what is left of the two main policy packages, on the one hand, legal immigration, and on the other hand, the "legalisation" procedure, is the phenomenon of illegal immigration. 
Legality covers the residence, on the one hand, of the migrants entering in the context of invitation/metaklisis or seasonal work and, on the other hand, migrants acquiring or renewing their papers by successfully participating in the "legalisation" program. Illegality applies to everyone else: migrants without a residence permit in their possession, even if these people once belonged to the first category, but in the process lost the documents legalising their residence.

Legality and illegality are not permanent or static properties, but rather dynamic phases or stages (étapes) in the migration process in the country of residence, which not only function alternately in numerous host countries (Schaeffer and Kahsai, 2011) but can alternate in the course of time. In the Greek case, in particular, the foreign population, especially those coming from third (non EU) countries, are living in a vicious circle of legalisation and, in particular, are permanently at risk of illegalisation (de-regularisation), and therefore under the fear of deportation, which has a catalytic effect on the lives of the removable persons, sometimes more than the very fact of the deportation decision (Schweitzer, 2014; DeGenova, 2002).

Removability is the dominant consequence or fundamental penalty of the lack of legality, which of course is perceived with different importance depending on the geographical distance of the country of origin or the country of expulsion and the administrative, legal and economic possibility of re-entering the country of destination. The prospect of deportation functions differently to the life of an Albanian citizen that can return, literally, even on the next day, and differently to the life of an Asian immigrant, who comes from thousands of miles away and has to repeat a distant, expensive and perilous journey.

In addition to eliminating the fear of deportation, legalisation of residence involves a number of benefits, notably the possibility of a conditional legal work and the enjoyment of most civil, social and insurance rights, reducing the gap between law and legality (Kurtovik, 2001). The illegal immigrant is deprived of an array of these rights (ESC, 2004?), although it is rightly supported that the distinction between Greeks and foreigners is alien to civil law, which is not the appropriate "place" for the legislator to exercise his policy against irregular immigrants in Greece (Mentis, 2014).

In addition, according to a controversial constitutional provision (Koukiadis, 2005), which is almost repeated verbatim in the context of all the basic laws on immigration since 1991 (Law 1975/1991), the transaction of undocumented immigrants with public authorities is prohibited, with a few exceptions ${ }^{3}$, most notably access to health services and only for emergency cases or cases of minors (Law 4251/2014).

Immigrants without valid residence permits in practice encounter severe difficulties in accessing education as regards their children (Greek Ombudsman, 2013), despite the explicit legislative provision in Law 3386/2005, under which the access to education for these children is established. This specific legal capacity is the product of persistent interventions by the trade unions and human rights organisations concerned.

Thanks to similar interventions (HLHR, 2007), the aforementioned provision remains practically inapplicable in the health sector as well. Nevertheless, the unofficial status and social

3. Another significant exception concerns the right of administrative and judicial protection of illegally employed immigrants. 
exclusion of immigrants are consistently important factors that adversely affect the immigrants' access to health services and generally undermine the defence of the right to health for these populations, especially in times of economic crisis (Economou et al ., 2014, Athanasopoulou et al., 2013, Linou et al., 2009).

Semi-legality is an intermediate concept between legality and illegality, since it refers to a state of waiting or limbo, which the immigrant experiences until the residence permit or, as applied formerly, the work permit and residence permit is issued (Konsta and Lazaridis, 2010). In these cases, the risk of deportation is minor, yet the degree of access to civil rights is limited. Often, the state proceeds to clarifications and delimitations of this special version of legality or illegality compared to what applies in the exercise of fundamental rights by legal immigrants.

Trapped in a legal ambiguity, the semi-official ones cannot be regarded as absolutely legal, nor absolutely illegal (Kubal, 2012): they sometimes have the right to residence or the benefit of non-deportation, but not the universal freedom of employment, sometimes the right to work, but not the freedom of movement, sometimes they enjoy part of the civil rights depending on the type or "quantity" of semi-legality. A key to qualifying for this intermediate category of semi-legality is the possession of a residence permit or, in particular, awaiting its issue after the application has been submitted.

In this sense, the absence of a residence permit or the prospect of acquiring it is a condition that does not allow the inclusion in the group of semi-official or semi-legal immigrants, of those immigrants consciously chosen by the state to be subject to another legal "state" or "phase", which is more governed by the principle of non-deportation than by the enjoyment of the limited rights usually enjoyed by semi-official immigrants.

\subsection{Para-legality}

More specifically, only recently has the Greek state enacted with a series of legislative interventions a new category of non (completely) legal immigrants, which could be called paralegality (пара-vopupótnta) and which is of great interest, particularly after the shift in the central philosophy of the country's migration policy observed after 2014, and the adoption of the Immigration Code. Five are the basic features of this new legality sub-category.

First of all, it concerns irregular immigrants who remain in the country in a status of deportation postponement (Law 3907/2011) or under protection against deportation (Law $3386 / 2005$ and Law 4332/2015). These are immigrants for whom deportation is not (directly) feasible for specific humanitarian reasons ${ }^{4}$ and to whom a specific relevant 6 months duration certificate is issued.

Secondly, a new form of work permit is reintroduced in the text of the relevant ministerial decision (M.D. 53619/735/25.11.2015), although the distinction between the work permit and

4. Reasons concerning: (a) the physical or mental condition of the alien, (b) technical difficulties, such as the deficiency of transport means or the objective impossibility of establishing the identity of the alien, and (c) the fulfillment of the conditions of the principle of non-refoulement (as described in international law provisions ratified by the country). 
residence permit has been abolished since 2005 (Law 3386/2005). In this case, a special work permit of 6 months duration is granted, without a right to access social integration programs, and renewable for 6 months, provided that the holder of the deportation postponement certificate is to adduce a certificate issued by a public health body certifying that he does not suffer by an infected disease.

Thirdly, this work permit entails specific sectoral and occupational limitations on the right to work, since the beneficiaries may only work in the sectors of agriculture and animal husbandry, in the sector of domestic work and in the clothing sector. In case the holder of the work permit was entitled to an employment pursuant to a previous legal residence permit which is no longer in force, the work permit may also be issued for the employment sector for which the beneficiary's work was authorised ${ }^{5}$.

Fourthly, it is explicitly stated in the work permit granted that the right to work does not concern the entire territory of the country, but is subject to certain geographical limitations. It is forbidden to work in the following areas: a) in the Regional Units of Evros, Xanthi and Rodopi of the Region of Eastern Macedonia and Thrace, b) in the Regional Units of the North Aegean Region and c) in the Regional Units of Kos, Rhodes, Karpathos and Kalymnos in the South Aegean Region.

Fifthly, this new regime is now potentially including all irregularly resident immigrants, if they wish to work exclusively in the rural economy. A recent amendment to Law 4384/2016 adds a new article (13a) to Law $4251 / 2014$ and the chapter on the process of invitation/ metaklisis system and seasonal work.

Summarising the new regulation, based on the special Circular 27430/2016, issued on $15 / 06 / 2016^{7}$, the new provision provides, exceptionally, for a 6 -month work permit to be issued in accordance with the above for non-removable aliens, in order to address emergency needs in agricultural holdings. A prerequisite is that the maximum number of invitations/metakliseis per year, as defined in the relevant two-year ministerial decree, is not to be completed.

During the period of validity of the work permit, the immigrant may conclude an employment contract with another employer within the same Region. The work permit constitutes a postponement of removal from the country and in the absence of a return decision by the competent administrative/ police bodies, the deportation decision is issued first and the postponement of removal is subsequently issued.

Vacant jobs should only concern the occupations of the agricultural labourer, shepherd and beekeeper, excluding poultry workers, those employed in housed husbandry farms and fishermen. The urgent and exceptional nature of the procedure is certified only by the employer's statement that he is in a situation of force majeure, on the ground that he is unable to conclude legal employment contracts in time to meet the needs of his holding. The request of the employer shall be approved by the competent service of the decentralised administration, if the type of farming and the acreage justify the employment of the number of workers included

5. Obviously, in the context of invitation/metaklisis system or seasonal work, thus mainly in the primary sector.

6. Which concerns agricultural cooperatives and forms of collective organisation in rural areas.

7. According to which certain semi-legal immigrants and specifically those who have applied for residence permit for exceptional purposes can fall under this procedure. 
in the application for the assignment of that number to the agricultural area or the livestock of the employer ${ }^{8}$.

From the aforementioned, three conclusions result concerning the case of para-legal immigrants.

First and foremost, there is a remarkably high degree of removability, since deportation is simply postponed and not inhibited and, simultaneously, a very low degree of enjoyment of civil and social rights. This is because the holders of this special work permit work according to the provisions of labour, insurance ("ergosimo" voucher system for occasional work) and tax legislation (M.D. 53619/735/25.11.2015) but do not have access to all other civil rights which entails a residence permit of a definite duration.

At the same time, this category of immigrants cannot be placed in between legality and semilegality, as it appears that the residence status remains irregular throughout the duration of the work permit. By combining features of both semi-legality and illegality, para-legality (napavopupuótnta) constitutes a parallel state of tolerance (of labour) into illegality (of residence).

Ultimately, this field of para-legality is a clear indication of the state's reluctance to tackle irregular residence and non-legal and yndeclared employment, particularly in the primary sector, as well as in the other two sectors: domestic employment and clothing. At the same time, it is proven that the recent deviation from the established work-based approach to migration policy for 1990-2014, as reflected in the Immigration Code, is neither a product of coherent strategic choice nor does it conceal a new philosophy oriented to the humanitarian approach of modern migration trends.

The Greek state once again claims "applause for innovation" as regards methods of institutional and officially established illegality (illegal residence), in order to maintain the status quo in the labour market unchanged, while at the same time attempting to promote a false image of immigration control and fight against undeclared and uninsured work, even in certain professions or sectors of the economy.

As regards the social acceptance of the new measure, it is likely that the willingness of employers and migrant rural workers to participate in the new system of legal work of illegally residing aliens seems doubtful. According to estimations provided by the Ministry of Migration Policy the total number of work permits issued under the new legislation do not exceed 1.500 by the end of 2017.

In the absence of serious and enforceable penalties, the advantages of totally or partially undeclared work (of legal, semi-legal or illegal immigrants) outnumber those of legal employment of para-legal immigrants. This is due to the fact that, for the employment of the latter, all the supporting documents provided for in the invitation/metaklis for seasonal work procedure (electronic administrative fee to the Greek state, detailed written contract of employment, proof of appropriate accommodation), as bureaucratic evidence, are recorded among the reasons of the general discouragement concerning participation in the official procedure of invitation/ metaklisis system for a great many employers, as well as for migrant workers.

8. As defined in the relevant Joint Ministerial Decision concerning the maximum number of residence permits in the context of invitation/metaklisis and seasonal work for the years 2015-2016. 
Nonetheless, it is possible in the medium term that there will be phenomena such as: a) increase in the maximum number of invitations/metkliseis on a two-year basis; b) great reluctance of employers-farmers and immigrants to cover these jobs and to be subject to the provisions on seasonal work or invitation and, by extension, c) rapid increase in applications for the special work permit for irregularly residing immigrants. Arguably, in other words, the recent legal conception may evolve into a new possibility for lawful farmer-employers to meet their labour needs, avoiding the extravagant and bureaucratic procedure of invitations/ metaklisis, and at the same time drawing employees from the internal tank of (irregularly residing immigrant) workers.

Ultimately, the geographical and sectoral limitations accompanying the right to work of para-legalised irregular immigrants constitute an extreme version of the explicit and public assumption that national migration policy, concerning almost exclusively the labour of immigrants, aims at a peculiar professional and legal entrapment of immigrants in the salaried employment of specific sectors of the Greek economy (Kapsalis, 2018).

The hybrid version of para-legality in Greek policy for migration and immigrant labour combines certain elements of legal immigration and legalisation, without, however, being a subindent of one or the other form of legality.

On the one hand, the elements that derive from the model of legal immigration are two. The first element concerns occupational limitations and the possibility of 6-month employment of non-removable immigrants in specific professions and sectors. The second element, which concerns, in particular, the category of irregular residents and holders of residence permits for exceptional reasons, is in close connection with the official procedure of inviting alien employees with the employers' initiative, characterised more as "domestic or inside invitation/ metaklisis". The shift towards national labour market to address the deficiencies of the legal migration system, with the terms and conditions applied to the invitation of seasonal workforce, indirectly justifies the view that the Greek framework for invitation/metaklisi from abroad is inherently ineffective and outdated, while the labour supply tank in Greece is inexhaustible, especially with regard to the rural economy (Marouda et al., 2015; ESC, 2010, 2004; Gemi, 2013; Kapsalis, 2010).

Patterns of "legalisation" are noted in the status of para-legality, since the system in question is aimed at irregularly residing and even under deportation immigrants, who for a certain period of time avoid the consequences of their illegal residence. Arguably, it would be wrong to consider that this is a new "legalisation" program of limited duration and extent, since, as already mentioned, there is no change in the residence status, which, in official terms, remains illegal.

\subsection{Legalisation}

According to the most common phrase, "legalisation of immigrants", which is detected in the texts of international organisations, independent bodies or even organisations defending immigrants' rights, the "legalisation" campaign or program refers directly and exclusively to the person of undocumented immigrants. The specific verbal reference to the residence status of 
these people is not the norm. On the contrary, the wording "legalisation of immigrants" is more frequent, whether it is in demand contexts by unions and political organisations, or for official reports and independent scientific work.

The prevalence of this terminology is indicative of the shift in the balance of the care of a legal system from the object of human behaviour to its subject. A legalisation object could be commercial affairs, incomes or arbitrary buildings, but not people. Although technically inadequate and socially and politically reproachable, the term "legalisation of immigrants" has potentially prevailed, since it clearly reflects the quintessence of the normalisations concerning irregular immigrants, as they refer to the person of the alien rather than the object of the movement, namely immigration itself.

Literally speaking, irregular immigration is not legalised, since it remains an illegal, hence administratively and criminally, punishable act, in accordance with the alien status law. The offender is the one who is amnested, either on a temporary (residence permit) or on a permanent basis (citizenship), but not his act, namely the irregular entry and residence in the country. Consequently, if the conditions for temporary and personal amnesty are eliminated, illegality is revived and the beneficiary of the "legalisation" program returns to an illegal residence status, which is defined ${ }^{9}$ as follows: "The presence in the Greek territory of a third-country national, who does not meet or has ceased to meet the entry conditions, as defined in Article 5 (1) of Regulation 562/2006 (Schengen Borders Code) or other conditions of entry, residence or stay of the legislation in force".

Besides, in the Greek "legalisation" programs, the claimant is exclusively the interested immigrant. It is them who attempt to exploit the opportunity offered by the state, theoretically to all immigrants (in practice, to a small part of them), to try to legalise, on their own initiative and with their own forces, the residence status by proving that they are working legally in accordance with the minimum conditions set each time.

According to the emerging "moral economy" of immigrants' illegality (Chauvin and Mascarenas, 2012), the people concerned are engaged in a constant effort to prove their “deservingness". In particular, illegal immigrants are encouraged, explicitly or implicitly, to collect uninterruptedly official or semi-official evidence of presence on the territory of the host State, evidence of credible work and financial behaviour, and other indications of behaviour that is consistent with "good citizenship", in view of a future "legalisation" or "naturalisation".

In the conscience of the illegally residing immigrant, the acquisition or renewal of "administrative traces" are a lifeline in his agonizing attempt to show -at the first chance- those features that will certify that he is a "good", useful or simply less "bad" irregular alien, who is entitled, possibly more than others, to a legal residence permit. Any other incentive for irregularly residing immigrants to participate in the para-legalisation procedure introduced by the Greek state cannot be perceived, especially if it requires the issue of the decision to remove them from the country after the expiration of the work permit.

This "immoral trap" in a particularly vulnerable position - against both the employer and the state - which is implied for the migrant worker by the theory of illegality (Bogg, 2013) and 
to a greater extent the theory of para-legality, is made by the host States on the basis of nonfull citizenship. Immigration is used to construct a "plastic" citizenship for the flexible shaping of different levels of subjects in terms of enjoyment of fundamental rights. In fact, as far as both documented and undocumented immigrants are concerned, modern states challenge in practice even the concept of "legal subject" (Kaltsonis, 2009).

During the continuum inclusion-exclusion in terms of legality, immigrants may belong to successive or simply in alternating "phases" or categories of citizens (Money, no dated). Legally they may be treated (Lazaridis, 2015) as: a) subjects, who enjoy all the rights of a citizen (Greek citizenship), b) excluded/ ejectés, namely semi-legal or legal immigrants, but without full rights of the citizen, c) included/ injects, which are protected by human rights, such as refugees, and d) outcasts/ abjects, namely marginalised persons, "inferior category" citizens, such as unofficial immigrants, to whom those subject to the new type of non-legality could be added, the para-legal immigrants.

This pendulum between legalisation and illegalization/ deregularisation, a fundamental feature of the Greek normalisation policy of irregular immigration, almost forces the entire immigrant population into contingently living conditions and under the constant risk of a legal rejection. The core of Greek migration policy, the work-based post-factum "legalisation", declares salaried employment as a key concept, which allows the gate to be crossed, leading not to the legal or formal labour market, but to legality.

In the Greek case, of course, this door operates just like the entrance in the American saloons. It opens and closes with ease, but the exit is usually sharp, impressive and quite painful.

\subsection{Migrant worker}

Not only is the "legalisation" policy focused on the subject of immigration, but in addition the very structure and set of rules that comprise the alien law, as is also suggested etymologically by the name of that branch of law. This law regulates the legal status of aliens, and therefore constitutes the branch of law that regulates the rights of aliens living and working in a territory (Papatheodorou, 2015; Papasiopi-Pasia, 2004; Lochak, 1985).

The foundations of the alien status law are, on the one hand, the foreign element and, on the other hand, the subject bearing this property, namely the non-native. The object of normalisation is the legal relationships that develop around a personal characteristic, the lack of citizenship of the state of residence. This is a law concerning the subject of immigration and its descendants, where the jus sanguinis guarantees the transmission of the foreign element to future generations.

On the contrary, labour law from its establishment barely values the subjective characteristics of persons, attaching minor importance to the element of nationality or other characteristics of the worker or the employer, which could, however, allow arguable adjustments to certain fundamental labour rules. The Article 4 of the Civil Code states that the alien enjoys the civil rights of the native. The distinction between Greeks and aliens is foreign to civil law (Mentis, 2014). 
Labour law, as an autonomous branch of law, could be defined as the set of rules that regulate all relationships formed on the basis of the provision of dependent work to an employer (Koukiadis, 2005; Couturier, 1990). An enabling condition for inclusion in the labour law provisions is the legal relationship of salaried work. Industrial relations constitute the total relationships and conditions that govern and shape the content of employment (Kouzis, 2001).

By the first focusing on the subject and the second on the object of human behaviour, the two branches of law typically develop with absolute autonomy. This means that, in political terms, the mechanisms and arguments for formulating more specific rules, at least in the Greek case, do not coincide.

In the first case, the host State's perception of citizenship, as part of its national narrative and the mythology that surrounds the nation and its identity, is coming first. The Ministry of the Interior ${ }^{10}$ is primarily competent for designing migration policy and for the establishment of alien law, providing for the internal order and security and focusing on the relations of citizens with the state authorities and the public services.

In the second case, labour and social security laws accurately reflect the correlations of power and competitive claims, on the one hand of workers, and on the other hand of employers and the state (Javillier, 1996), reflecting the effect of the distribution of wealth produced between capital and labour (Kouzis, 2001). In the Greek case, the competent Ministry of Labour rarely takes initiatives or plays a leading role in shaping policy on migration or even the labour of migrants.

The two branches of law, however, have a point of intersection in the labour relations of immigrant workers, namely the overwhelming majority of migrant workforce. The salaried employment of immigrants is the field on which apply both the provisions relating to the person of the alien and those relating to the dependent labour relationship with an employer. In the

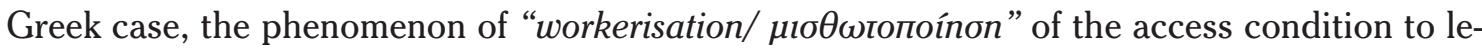
gality or, more specifically, the proletarianisation of the participation condition, either in legal immigration or, most importantly, in the legalisation of residence, is observed.

From 1991 to at least 2001, salaried work is the exclusive "passport" of entry into the protective context of the Greek legal order and temporary legality. The legal regime in force from 2001 to 2014 does not downgrade the importance of possessing this "passport". On the contrary, along with other secondary conditions of legality, it gives the salaried employment a central role in activating other parallel tools for acquiring legal residence (such as family reunification). On official terms, this salary-workerisation of legality conditions for immigrants becomes more loose from 2014 (Law 4251/2014), yet this is an ostensible and exogenously imposed shift, subject to revisions and arguable adjustments, as demonstrated by the recent introduction of forms of para-legality.

In addition, the Greek State carefully poses legal obstacles and devises institutional difficulties to avoid this scenario towards legality, artificially entrapping the prospect of "legalisation" in salaried work. The significantly larger number of social security stamps/ensima for independent economic activity, as well as the required bank capital of 60,000 euros for the renewal of the relevant permit, make this form of employment almost prohibitive for the average immi- 
grant ${ }^{11}$. The number of these permits, according to the Ministry of Interior (30/06/2016), does not exceed 160. At the same time, the geographical and professional limits often accompanying dependent work act as forms of absolute "attachment" of immigrants to salaried employment, making - for a long period of time - even the state of unemployment itself particularly damaging.

Proof of the (required quantity of legal) salaried work with specific terms imposed by the state (number of social security stamps per employment category) is a prerequisite for successful participation in the "legalisation" program. Therefore, the key to understanding the conception and construction of illegality in Greece is the concept of the migrant worker or, secondarily, of the employed migrant. Concerning residence and employment, legal integration appears to be too weak for all categories of migrants, with the exception of EU migrants and aliens of Greek nationality, namely the "privileged" migrants, who are treated under special legislation (Baldwin-Edwards, 2005), rather than focusing on the relationship of dependent work and its particular qualitative and quantitative aspects.

\section{Conclusions}

Based on the aforementioned, it appears that the "migrant worker" is not just a category of worker or employee, but in essence is a legal construction that introduces a new legal entity. This is potentially a particular category of citizen, for whom some aspects of their professional life and general economic and social behaviour can determine to a significant extent the integration into the national legal framework of the host country.

It becomes clear from the justification reports and the letter of the legislative interventions that, although the approach of the Greek migration policy is work-based, migration law does not typically seek to regulate the object (of the industrial relations), but to form the properties of the subject (of the transnational mobility) with a focus on legality. In fact, however, by means of the residence status and the construction of the migrant work, migration law interferes in an indirect but definitive manner in the field of industrial relations as well.

This strategic choice is a clear indication that the labour relations between migrant workers and their employers are quasi-tripartite, presenting a strong public dimension, since the state and its services are actively involved in various ways, both before and during the conclusion, as well as in the operation or the perspective of these industrial relations. In the alien law, the ability to enter into an employment relationship, its content and its duration, its type and the formalities of insurance depend to a large extent, if not exclusively, on the status of the alien natural person ${ }^{12}$, as attributed by the states in the context of national or european law.

And this does not only apply to the case of invitation/metaklis, where the role of the state is dominant at all levels (pre-authorisation of entry, determination of the maximum number

11. The jurisprudence of the Greek courts adds the obligation to document the way in which the relevant capital is acquired and the full proof of the legal way in which these capitals are acquired (Decision of the Council of State, 475/2013).

12. Native or non-native, EU or third-country national, documented or undocumented, first or second generation, and so on. 
of invited employees, imposing a bank guarantee, etc.). It also applies to the "legalisation" of residence status through specific legal requirements, such as the mandatory deposit of a written contract to the public authorities or proof of the minimum social security coverage (number of stamps) with public documents and the requirement to collect several public certificates for the authorisation of the conclusion of a dependent work contract.

Under the pretext of immigrant status or alien status of the worker, the shift in the balance from the object to the subject is ensured, so as they are excluded from the universal application of labour law. The personality of the migrant worker is "overwhelmed" as a result of the influence of two opposing forces: on the one hand, the restrictive provisions of the alien law focusing on the subject and on the basis of the lack of Greek citizenship and, on the other hand, the labour law which tries on the basis of its universality to include in its scope the industrial relations of aliens as well. Located in-between the labour law, the migrant worker walks the line between two boats, which are at risk of being capsized by a flood of special labour laws that tend to form a new sub-category of labour law, the migration labour law (Kapsalis, 2018).

The recent legal invention, para-legality, which in its function introduces a new sub-category of limited rights entities and a novel semi-subject of lawt, does not even look forward to the benefits of a semi-legal immigrant. Maintaining high levels of removability, para-legality, as an internal invitation procedure, is a blatant case of return to the past of a work-based migration policy and, at the same time, a clear promise for the continual inventing of techniques to avoid a holistic regulation of the working and residence status of immigrants in terms of equality and justice.

Therefore, the shift in 2014 towards a strategy to facilitate the retention of residence status with an emphasis, not so much on the labour factor, but on the actual fact of long-term residence, is lost in a cluster of targeted political choices, which will perpetuate the regulation of immigrants' salaried employment, not on the basis of the object of the labour relationship, but on the basis of the employee's nationality and his desired sectoral, geographical and occupational immobility.

\section{Bibliography}

\section{GREEK-LANGUAGE}

Athanasopoulou Maria, Mechili-Enkeleind Aggelos, Athanasopoulou Aggeliki and Diomidous Marianna (2013), "Factors affecting immigrant's health and their impact in Public Health", Interscientific Health Care, 5 (5), pp. 162-167.

Baldwin-Edwards Martin (2005), The Integration of Immigrants in Athens: Developing Indicators and Statistical Measures, Panteion University.

Cavounidis Jenny (2012), "The Labour Market Integration of Migrants in Greece”, in Kasimis

Charalambos \& Papadopoulos Apostolos (edit.), Immigrants in Greece, employment and integration in local societies, publ. Alexandria, pp. 69-104. 
ESC/ Economic and Social Committee (2016), Human flows in Greece: aspects and consequences of the refugee and migration issue, Initiative Opinion no. 317, November 2016.

ESC/ Economic and Social Committee (2010), Initiative opinion on migration, Opinion no. 229, February 2010.

ESC/ Economic and Social Committee (2004), Migration and the cooperation among States in the Mediterranean, Opinion 110, July 2004.

Gemi Eda, Alavanos Giannis, Apostolidis Michalis kaı Panourgia Kyriaki (2010), Temporary and circular migration, European Migration Network, October 2010.

HLHR/ Hellenic League for Human Rights (2007), Right to health of immigrants without legal residence documents, Report, 08/11/2007.

Kaltsonis Dimitris (2009), "Immigrants, law, democracy, Presentation in the Conference "Social inequality in modern Greece", November 27-28 2009, Panteion University.

Kapsalis Apostolos (2018), Migration and labour in today's Greece, Publ. Topos (under publication).

Kapsalis Apostolos (2012), “Undeclared work and immigration: 'legalisation' of immigrants through their work or legalisation of their work», in Kasimis Charalambos \& Papadopoulos Apostolos (edit.), Immigrants in Greece, employment and integration in local societies, publ. Alexandria, pp. 183-210.

Kapsalis Apostolos (2007) (edit.), Undeclared employment and "legalisation" of immigrants: the challenge of Migration Policy, INE/GSEE, Studies (27).

Kotzamanis Byron and Karkouli Alexandra (2016), The migrant inflows in Greece during the last decade: intensity and basic characteristics of the irregular migrants and the asylum seekers, Demographic News, Laboratory of Demographic and Social Analyses, issue 26.

Kouzis Giannis (2001), Labour relations and European Integration: flexibility and deregulation or improvement of labour?, INE/GSEE, Studies (14).

Koukiadis Ioannis (2005), Labour law: individual labour relations and the law of work flexibility, publ. Sakkoula.

Kurtovic Ioanna (2001), "Immigrants: between law and legality", in Marvakis Athanasios, Parsanoglou Dimitris and Pavlou Miltos (edit.) (2001), Migrants in Greece, publ. Ellinika Grammata, pp. 163-198.

Linou Athina, Kotsioni Ioanna, Chatziprokopiou Panos and Riza Eleni (2009), Report on migrants' health in Greece, National and Kapodistrian University of Athens, March 2009.

Marouda Maria-Daniella, Saranti Vasiliki, Koutsouraki Eleni and Papaioannou Maria (2015), Defining the labour force inadequacies and the need for labour force migration from third countries of the European Union, Institute of International Relations, Panteion University.

Mentis Georgios (2014), "Migrants and civil law", Private Law Chronicles, 5, pp. 396-400.

Papatheodorou Theodoros (2015), Alien legal status: Greek and European legislation, publ. Nomiki Bibliothiki.

Papasiopi-Pasia Zoi (2004), Alien status law, publ. Sakkoula.

The Greek Ombudsman (2013), Non-enrollment and non-promotion to the next grade of underage foreign students, due to the lack of enrollment documents, December 2013. 
Balch Alex (2010), Managing labour migration in Europe: ideas, knowledge and policy change, Manchester University Press.

Baldwin-Edwards Martin (2004), Immigration into Greece, 1990-2003: a southern European paradigm?, MMO, UNECE.

Bansak Cynthia (2016), Legalizing undocumented immigrants, IZA, March 2016.

Banulescu-Bogdan Natalia and Fratzke Susan (2015), Europe's migration crisis in context: why now and what next? , Migration Policy Institute, September 2015.

Bogg Alan (2013), «The immoral trap: migrants workers and the doctrine of illegality», in Ryan Bernard (ed), Labour Migration in hard times: Reforming labour market regulation? , The Institute of Employment Rights, p. 119-140.

Brick Kate (2011), Regularizations in the European Union: the contentious policy tool, Migration Policy Institute, December 2011.

Chauvin Sébastien, Garcés-Mascarenas Blanca and Kraler Albert (2013), Working for legality: employment and migrant normalisation in Europe, IOM.

Chauvin Sébastien and Garcés-Mascarenas Blanca (2012), «Beyond informal citizenship: the new moral economy of migrant illegality», International Political Sociology, 6, p. 241-259.

Couturier Gérard (1990), Droit du travail : les relations individuelles du travail, éd. PUF.

DeGenova Nicholas (2002), «Migrant illegality and deportability in everyday life», Annual Review of Anthropology, 31, p. 419-447.

Doomernik Jeroen and Jandl Michael (2008) (eds.), Modes of migration regulation and control in Europe, Amsterdam University Press.

Economou Charalambos, Kaitelidou Daphne, Katsikas Dimitris, Siskou Olga and Zafiropoulou Maria (2014), «Impacts of the economic crisis on access to healthcare services in Greece with a focus on the vulnerable groups of the population», Social Cohesion and Development, 9 (2), p. 99-115.

Finotelli and Arrango (2011), «Normalisation of unauthorized immigrants in Italy and Spain: determinants and effects», Documents d' Analisi Geografica, 57 (3), p. 495-515.

Flynn Don and Duvell Frank (2007), Undocumented migrants: symptom, not the problem, PICUM, April 2007.

Gemi Eda (2013), Albanian irregular migration to Greece: a new typology of crisis, ELIAMEP. Hollifield James, Martin Philip and Orrenius Pia (2014), «Dilemmas of immigration policy», in Hollifield James, Martin Philip and Orrenius Pia, Controlling Immigration, Stanford University Press, third edition, p. 3-34.

ICMPD/ International Centre for Migration Policy Development (2009a), Normalisations in Europe, REGINE program, Appendix A, Country Studies, January 2009.

ICMPD/ International Centre for Migration Policy Development (2009), Normalisations in Europe, REGINE program, Final report, January 2009.

Javillier Jean-Claude (1996), Droit du travail, éd. LGDJ.

Kapsalis Apostolos (2010), Labour integration of immigrants in Greece, National Report, Inde- 
pendent Network of Labour Migration and Integration Experts, IOM-European Commission, (www.labourmigration.eu), March 2010.

King Russell and DeBono Daniela (2013), «Irregular migration and the 'Southern European Model' of migration», in Journal of Mediterranean Studies, Vol. 22 (1), p. 1-31.

Koehler Jobst, Laczko Frank, Aghazarm Christine and Schad Julia (2011), Migration et crise économique: implications politiques au sein de l'Union Européenne, Mai 2011, OIM.

Konsta Anna Maria and Lazaridis Gabriella (2010), «Greek migration policy: civic stratification, 'plastic' citizenship and 'plastic subjectivities' in Greek Immigration Policy», Journal of International Migration and Integration, 11 (4), p. 365-382.

Kraler Albert (2009), Normalisation: a misguided option or part and parcel of a comprehensive policy response to irregular migration?, IMISCOE, Working Paper 24.

Kubal Agnieszka (2012), Conceptualizing semi-legality in migration research, Working Paper 32, International Migration Institute, University of Oxford.

Lazaridis Gabriella (2015), International migration into Europe: from subjects to abjects, Palgrave MacMillan.

Lockak Danièle (1985), Etrangers: de quel droit?, éd. PUF.

Maas Willem (2010), «Unauthorized migration and the politics of regularization, legalization and amnesty», in Menz Georg and Caviedes Alexander (eds), Labour migration in Europe, ed. Palgrave, p. 232-250.

Mc Govern Clair (2014), Regularization programs within the European Union: an effective tool to manage irregular migration?, UNU-GCM.

Money Jeanette (no dated), Comparative immigration policy, University of California.

Nascimbene Bruno (2000), «Immigration legislation reform in Italy: the international and European community frameworks», Revue des Affaires Européennes/Law \& European Affairs, p. 94-106.

OECD/ Organisation for the Economic Cooperation and Development (2000), Combating the illegal employment of foreign workers, OECD.

Papadopoulou Aspasia (2005), Normalisation programmes: an effective instrument of migration policy?, Global Migration Perspectives, No33, GCIM.

Reyneri Emilio (2001), Migrants' involvement in irregular employment in the Mediterranean countries of the European Union, University of Milan Bicocca, January 2001, ILO.

Rodier Claire (2001), «Les régularisations dans les pays du sud de l'Europe et en France», Migrations Société, 74, Mars-Avril 2001, p. 59-68.

Rosenblum Marc (2014), «Overcoming the challenges of immigration control», in Hollifield James, Martin Philip and Orrenius Pia, Controlling Immigration, Stanford University Press, third edition, p. 35-39.

Schaeffer Peter and Kahsai Mulugeta (2011), «A theoretical note on the relationship between documented and undocumented migration», International Journal of Population Research, p. 1-7.

Schweitzer Reinhard (2014), The making and unmaking of irregular migration: migrant 'illegality', regularization and deportation in Spain and the UK, Integrim Online papers, 4/2014.

Triandafyllidou Anna and Ambrosini Maurizio (2011), «Irregular immigration control in Italy and Greece: strong fencing and weak gate-keeping serving the labour market», European Journal of Migration and Law, 13, p. 251-273. 